\title{
Whereto for Maintenance Law as Child Support Grants and Defaulters Put It to the Test
}

\author{
Neo Morei \\ Senior Lecturer, Faculty of Law, North-West University \\ Email: neo.morei@nwu.ac.za
}

\section{Doi:10.5901/mjss.2014.v5n20p756}

Abstract

The paper explores the challenges faced by South African children in need of maintenance against the backdrop of the solid South African legal framework that regulates this sphere and questions the resonance between such legal framework and their day to day experiences. This applies to both parental and state grants. It continues to assess the effectiveness of the state enforcement mechanisms employed to deal with child maintenance and makes recommendations in that regard. Crudely put, South African children in need of maintenance face perennial challenges in the form of inadequate provision of means of support for their physical, mental, spiritual, moral and emotional development.

Keywords: South Africa, children, maintenance, legal framework, Child Support Grants

\section{Introduction}

South Africa is faced with an increasing number of children who are abandoned and left with no means of support. Those who are not abandoned are seldom supported by both parents. Some fathers have shunned the responsibility to take an active role in the upbringing of their children, leaving the sole responsibility with the mother who in most cases is never absent. The state, for its part, provides some support to children whose parents cannot do. This is done in the form of child support grants which those with cynical views may see as contributing towards the ease with which teenagers seem to accept the responsibility to having children. ${ }^{1}$ The state also meets its obligation by funding other social grants such as foster child grant, care-dependency grant and by establishing welfare programmes, such as free health care for children under six years of age and the National School Nutrition Programme. ${ }^{2}$ However, the unanswered question remains whether the rise in child bearing, especially among teenagers, can be attributed to the government's Child Support Grant system (CSG). ${ }^{3}$ These challenges ultimately lead to the state assuming some degree of financial responsibility for dependent children.

The Constitution of the Republic of South Africa, 1996 provides that every child has the right to family and parental care, basic nutrition, shelter, basic health care and social services. ${ }^{4}$ It also emphasizes the paramountcy of the best interests of the child principle in all matters concerning a child. ${ }^{5}$ Children have a right to proper parental care. It is universally recognized in the context of family law that the best interests of the child are of paramount importance. ${ }^{6}$ While the obligation to ensure that all children are properly cared for is an obligation that the Constitution imposes in the first instance on their parents, ${ }^{7}$ there is an obligation on the state to create the necessary environment for parents to do so.

In Bannatyne $v$ Bannatyne and Another ${ }^{8}$ the court held that the state must provide the legal and administrative infrastructure necessary to ensure that children are accorded the protection contemplated by section $28 .{ }^{9}$ The same sentiment was expressed by the court in the case of Soller v Maintenance Magistrate of Wynberg and Others ${ }^{10}$ where it

\footnotetext{
${ }^{1}$ According to $\mathrm{G}$ Hosken in his article titled SA's Children's Misery available at www.timeslive.co.za about 10.3 million children depend on the government's monthly R270 child support grant and one million children who are eligible for grants do not receive them. He further submits that four out of ten children live in homes where no one is employed. In cases of dire poverty, this figure increases to seven in 10 children.

2 J Heaton South African Family Law $3^{\text {rd }}$ ed LexisNexis (2010) 321

${ }^{3}$ The number of child support grant recipients increased by $1200 \%$ from 800476 in 2001 to 10, 387, 238 in 2011. This number is envisaged to increase to 11303077 in 2013 . See S Dunlop "Can South Africa afford a welfare state? available at http://www.parent24.com/preschool accessed 23- 11-2013.

${ }_{4} \mathrm{~S} 28$.

5 This principle is legislatively entrenched in s 28(2).

6 International law also affirms the 'best interest' principle and many countries have subsequently incorporated it into their constitutions or child and family legislation. Article 3(1) of the United Nations Convention on the rights of the Child, requires that ' in all actions concerning children, whether undertaken by public or private social welfare institutions, courts of law, administrative authorities or legislative bodies, the best interests of the child shall be a primary consideration. See also article 4(1) of the African Charter on the Rights and Welfare of the Child, 1990.

7 Government of the Republic of South Africa $v$ Grootboom and Others at para 77.

${ }^{8} 20032$ BCLR 111 (CC), 20032 SA 363 (CC).

9 Grootboom ibid para 78.

1020043 ALL SA 235 (C).
} 
was also held that the maintenance court functions as as a unique or sui generis court and it exercises its powers in terms of the provisions of the maintenance Act and it does so subject to the relevant provisions of the Constitution, more specifically section 28(2). Case law has laid down the factors courts should consider when evaluating the best interests of the child. ${ }^{11}$

Section 7 of the Children's Act 38 of 2005 has codified a comprehensive list of factors pertaining to the best interests of the child. ${ }^{12}$ South Africa has also signed and ratified a number of international instruments, ${ }^{13}$ and has therefore assumed certain international obligations relating to child support. ${ }^{14}$ The right to social security is reiterated in the United Nations Convention on the Rights of the Child (CRC), which recognizes the right of every child to benefit from social security. ${ }^{15}$ However, article 18 of the CRC emphasizes that the parents have the primary responsibility for the upbringing and development of the child. Parents or legal guardians have the 'primary responsibility' in this regard and the 'best interests' of the child is to be 'the basic concern.' That the responsibility is 'primary' rather than 'exclusive' suggests that the secondary responsibility will lie with the state. For the purpose of guaranteeing and promoting the Convention rights, states 'shall render assistance to parents and legal guardians in the performance of their child-rearing responsibilities and shall ensure the development of institutions facilities and services for the care of children. ${ }^{16}$ State parties are obliged to take all appropriate measures to secure the recovery of maintenance for the child from both parents within the country and abroad. ${ }^{17}$ In instances where South Africa is not bound by a treaty it is mandatory in terms of the Constitution that when interpreting the Bill of Rights, a court, tribunal, or forum must consider international law. ${ }^{18}$ It is clear that the onus is now on the government to take positive steps to ensure that these rights are realised. This obligation has been positively discharged through legislative enactments. ${ }^{19}$ According to the Children's Act maintenance is one of the elements of parental responsibilities and rights. ${ }^{20}$ Parental responsibilities and rights includes the right to care for the child, to maintain contact with the child, to act as guardian of the child and to contribute to the maintenance of the child. ${ }^{21}$ The Children's Act, therefore subtly shifts the duty of support (maintenance) so that it becomes one of the aspects of parental responsibilities and rights. ${ }^{22}$

The purpose of this paper is to give a brief exposition of the law on child maintenance, the effectiveness of the law on maintenance and furthermore, give an overview of the state's machinery in the enforcement of the duty of parents to maintain their children. It will also be determined whether the state through the Child Support Grant Programme has assisted where parents are unable to contribute adequately.

\section{Maintenance: Basis and Scope of the Duty of Support}

Maintenance, support or alimony are used interchangeably at common law to denote not only the necessities of life, such as food, clothing and shelter, but also extends to education and care in sickness, furthermore the child must be provided with all those things which are required for his or her proper upbringing.23 Parent's duty to support their children, whether legitimate or illegitimate was established in Roman and Roman-Dutch law, and has been affirmed in many decisions of our courts and it is apparent that the absence of a duty to maintain in accordance with customary law is no defence.24 The duty of parents to support their children exists by the operation of law and flows from blood relationship or adoption. 25 The duty rests on both parents during the marriage and after their separation and divorce and it is distributed according to their respective means and income.26 The duty comes into effect at the birth of a child and continues until

\footnotetext{
11 McCall v McCall 19943 SA 201 (C).

12 A Skelton, M Carnelley, S Human, JA Robinson \& B Smith Family Law in South Africa 1 ed (2010) 141.

${ }^{13}$ The International Covenant on Economic, Social and Cultural Rights (ICSECR) was signed by South Africa on the $3^{\text {rd }}$ of October 1994 but has not yet been ratified. The convention recognizes the right of everyone to social security, including social insurance. The right to social security is reiterated in the United Nations Convention on the Rights of the Child (CRC), which recognizes the right of every child to benefit from social security. It was ratified by South Africa in June 1995.

${ }_{14}$ B Clark "Duties of support of living persons" in Boberg's Law of Persons and the Family 2 ed (1999) 233 259-260.

15 Clark "Support of living persons" in Boberg's Person's and the Family" 259.

16 Art 18(2).

17 Article 27(4)

18 S 39(1)(b).

19 Maintenance Act 88 of 1999, Children's Act 38 of 2005 and other social security enactments.

20 The Children's Act re-confirms the traditional concept of 'parental power as parental responsibilities and rights implying that parents still have some kind of authority over the children in their households but at the same time makes it clear that parents have rights and powers in order to fulfill their obligations towards the child. See in this regard Domingo et al Law of Persons and the Family Pearson Education South Africa (Pty) Ltd 2012 at 185. Furthermore, section 1(1) of the Children's Act includes the duty of support under the 'care' element of parental responsibilities and rights.

${ }^{21}$ Section 18 (2) of Act 38 of 2005

22 Skelton $n 12$ at 242.

23 E Spiro Law of Parent and Child 4 ed (1985) 397.

24 Boberg Persons and the Family 240.

25 Spiro Parent and Child 385.

26 JA Robinson Children Young Persons and their Parents (1997) 68
} 
the child is in a position to support himself/herself.27 The duty is not terminated by the death of a parent but continues even after death as long as there is a need.28 In Bannatyne v Bannatyne29 (Commissioner for Gender Equality, as Amicus Curiae) the Constitutional Court held that the child's parents and family are primarily responsible for caring and providing for the child and that the duty which section 28 (1)(c) refers to rests primarily on the child's parents and family. It passes to the state only if the child's parents and family fail or are unable to meet their obligations. The duty which section 28(1) (c) imposes, is at least partly related to providing the child with support. Furthermore, although maintenance has not been defined in the Children's Act and still retains its common law meaning, the concept of parental responsibilities and rights also includes the responsibility and right to contribute to the maintenance of a child.30

\subsection{Requirements for the existence of a duty of support}

Legally parents are obliged to maintain their children if the following requirements are met: ${ }^{31}$

1. Parents have the necessary means to provide maintenance.

2. The child is unable to maintain himself/herself and there is a need for maintenance.

3. The relationship between the person entitled to maintenance and the person obliged to provide maintenance must be of such a nature that the law imposes a duty to support.

\subsection{The scope of the duty of support}

The scope of the duty of support depends on the circumstances of each case. The extent to which maintenance must be provided, depends on the social status and financial position of the family. ${ }^{32} \mathrm{~A}$ child may therefore be entitled to more than just the basic necessities of life. ${ }^{33}$ In appropriate circumstances, a child may be entitled to a university or other postschool education possibly even if it extends beyond attainment of majority.

\subsection{Maintenance orders and their enforcement}

The Maintenance Act 99 of 1998 creates the most important enforcement mechanism in the legal system. ${ }^{34}$ The Act provides a fair and equitable, simple and quick procedure by means of which liability to support can be enforced. It applies in respect of the legal duty of any person to maintain any other person irrespective of the nature of the relationship between those persons giving rise to the duty. ${ }^{35}$ There are various civil and criminal enforcement mechanisms to ensure that the maintenance order is honoured. A parent who fails to comply or refuses to comply with a maintenance order is guilty of an offence and a fine or a term of imprisonment (with or without the option of a fine) may be imposed. ${ }^{36}$ In addition, the court may make an order, having the effect of a civil judgment, ${ }^{37}$ for the recovery of the unpaid maintenance. Such an order can be executed against pensions, gratuities or similar benefits normally immune from attachment for civil debts. ${ }^{38}$ The maintenance court may authorize the issue of a warrant of execution against the movable property of the maintenance debtor ${ }^{39}$ If the movable property is insufficient to satisfy the order, it may then issue a warrant of execution against the immovable property to the amount necessary to cover the amount the person has failed to pay including any interest as well as the costs of the execution. ${ }^{40}$ Furthermore, a maintenance court may make an order for the attachment of any emoluments against the maintenance debtor ${ }^{41}$ and also an order for the attachment of any debt for the amount necessary to cover the amount the person has failed to pay, together with any interest thereon, as well as the costs of the attachment or execution. ${ }^{42}$

\footnotetext{
$27 \mathrm{~J}$ A Robinson et al Introduction to South African Family Law $4^{\text {th }}$ ed 2009 at 266, parental duty of support also exists in terms of the common law and has been legislatively entrenched in section 15 of the Maintenance Act.

28 In principle, the common law duty of support terminates when the child no longer needs support. Thus, even if the child, the common law support duty will lapse if the child inherits a fortune, for example. See in this regard Domingo W et al Law of Persons and the Family Pearson 2012 at 191.

${ }^{29}$ See $n 8$ supra.

$30 \mathrm{~S} 18(2)(d)$.

31 JA Robinson, S Human, A Boshoff \& BS Smith Introduction to South African Family law (2002) 239.

32 DSP Cronje \& J Heaton South African Family Law $3^{\text {rd }}$ ed (2010) 324.

33 See Chamani v Chamani 19794 SA 804 (W); Mentz v Simpson 19904 SA 455 (A) and Smith v Smith 19803 SA 1010 (O).

34 Skelton et al Family Law 356

35 S 2(1).

36 S 31(1)

37 S 24(1)

38 Clark "Enforcement of the duty of support" in Boberg's Persons and the Family 292

39 Section 27.

40 Skelton $n 34$ at 358

41 Section 28.

42 Section 30.
} 
In Mngadi v Beacon Sweets \& Chocolates Provident Fund ${ }^{43}$ the court ordered a provident fund to retain the lump sum withdrawal benefit of the children's father and to make monthly payments from the benefit I respect of the children's future maintenance. ${ }^{44}$ In casu, the father had resigned from his job in order to escape paying maintenance. ${ }^{45} \mathrm{He}$ was not in arrears at the time of the present order but had been in arrears in the past. The court found that were he allowed to withdraw his provident fund benefit he would most probably 'either secrete it away, spend it on himself or otherwise dissipate it' and would not nuture it carefully and preserve it to perform his maintenance obligations'. ${ }^{46}$

A similar order was granted by the court in Magewu $v Z^{2} z_{0}{ }^{47}$ in respect of the pension withdrawal benefit of a maintenance debtor who had been retrenched. In Soller v Maintenance Magistrate, Wynberg ${ }^{48}$ the court held that the maintenance debtor's continual defaulting on his maintenance payments justified an order that a retirement annuity fund be prohibited from making payments to the maintenance debtor unless the Maintenance Court or the maintenance debtor's former wife (who had care of the couple's minor child) consented to such payment. ${ }^{49}$ The fund was further ordered to make annual maintenance payments from the annuity to the child's mother until the child became selfsupporting..$^{50}$ The maintenance court may also authorise the issue of a warrant of execution against the movable property of the maintenance debtor. ${ }^{51}$ This means that the defaulter's property is sold and the proceeds of the sale are used to pay the maintenance. If the movable property is insufficient to satisfy the order, it may then issue a warrant of execution againgst immovable property to the amount necessary to cover the amount the person has failed to pay plus interest. ${ }^{52} \mathrm{In}$ Burger $v$ Burge $r^{53}$ the maintenance debtor had resigned from his employment and was still unemployed. He did not offer any reason for his resignation nor made any serious attempts to obtain new employment. He had fallen into arreas with his maintenance payments and a writ of execution against his property had failed to produce any money. The court then ordered the attachment of the debtors portion of the proceeds of the sale of immovable property in order to secure maintenance for his children. A maintenance court may also make an order for the attachment of any emoluments against the maintenance debtor. ${ }^{54}$ This means that the outstanding amount is paid directly by the defaulter's employer. A maintenance court may also make an order for the attachment of any debt. ${ }^{55}$ In this instance, any person or company that owes the defaulter money will be ordered to pay maintenance directly to the person to whom money is owed, instead of the defaulter. However, if a person proves that they have no means to pay maintenance and that it is not due to unwillingness to work or wrong doing on their behalf, then a court cannot enforce a maintenance order.

\section{Challenges of Adequate Implementation}

It is submitted that although the Maintenance Act complies fully with the provisions of the United Nations Convention on the rights of the Child,56 it has made minimal impact in ensuring that parents take the responsibility to support their children seriously. This can be seen in the increasing number of children who are registered for the government's Child Support Grant (CSG).57 The introduction of "no fee schools" in the public education sector is another factor which has been attributed to by the lack of payment of school fees which is indicative of the fact that parents are failing in their duty to provide for their children. Although there are many factors which influenced the government in the provision of these schools,58 absent parents (particularly fathers) are partially responsible for the introduction of these schools. It is often argued that modern fathers are taking interest in the welfare of their children but this does not seem true for South Africa, because the system is still faced with a high rate of defaulting fathers with regard to child maintenance.59 These absent

\footnotetext{
432003 (2) ALL SA 279 (D), 2004 (5) SA 388 (D).

44 Heaton op cit $n$ at 57 .

45 Ibid.

46 Ibid.

4720043 ALL SA 235 (C)

4820062 SA 66 (C).

49 Heaton op cit $n$ at 58

50 Ibid.

51 S 27.

52 Skelton $n 40$ at 358

${ }^{53} 20064$ SA 414 (D).

$54 \mathrm{~S} 28$.

$55 S 30$

56 Article 27 of the Convention for instance, requires state parties to recognize the right of every child to a standard of living which is adequate for the child's physical, mental, spiritual, moral and social development and to take all appropriate measures in order to secure the recovery of maintenance from the parents or other persons having financial responsibility for the child. In some instances, however, what the Convention requires is not that the state itself should assume the full burden of protecting rights but that it should ensure that other individuals do so; in such instances, the role of the state is to assist others in the discharge of their responsibilities and to take appropriate action where they fail to do so.

${ }^{57}$ According to the Children's Institute, UCT by November 2011, 10 615, 923 children were receiving grants per month, see statistics on children in South Africa available at http://www.childrencount.ci.org.za/social accessed 10 -12-2013.

58 For example, unemployment, poverty, child-headed households caused by the HIV and AIDS pandemic.

${ }^{59}$ Clark "Enforcement of the Duty of Support" in Boberg's Law of Persons and Family 279 291-294.
} 
fathers are draining state resources and it is not fair that tax contributions of citizens are used to support the children of such fathers. Although poverty is rife in rural areas and parents who are unemployed are unable to pay maintenance, such lack of resources cannot be an excuse, parents must find lawful means to support their children. Where the courts have successfully executed an order and a garnishee order has been obtained against the defaulting parent's salary, there are other challenges of enforcements such as non- availability of assets to attach as in many cases defaulters conceal whatever assets they may have had, often some were members of retirement funds and were building up pension benefits- effectively one of the only assets in the estate of the party.60 These benefits could not be attached by their creditors and this included, spouses and children61 or such parents often resign from their employment and simply disappear. However, this situation has improved as section 16 of the Maintenance Act now allows the maintenance court to address any pension fund administrator and order that the administrator to make payment of those annuities to the dependants of that pension fund member.62

The criminal justice system finds it difficult to trace defaulting fathers.63 The courts are sometimes lenient in dealing with maintenance cases and poor procedural mechanisms for enforcement are prevalent; a lack of realistic attempt to assess the costs of raising children or to clarify the principles of child support all compound the issue of child support.64 The problem is further exacerbated by mothers who sometimes do not know the full identity of the father because in order to facilitate and initiate a maintenance enquiry and subsequent successful acquisition of the maintenance order, the maintenance officer should be furnished with full names and surname of the father.65 More often the mother would know the father as one 'John' or 'David' and have the correct address but without John's surname and possibly his identity number it is very difficult to serve summons on him. It is conceivable that in some cases 'John' or 'David' would simply say 'I am not John' and the summons will not be served on him.

Unemployment is a serious problem in South Africa and many absent fathers are unemployed and are unable to provide for their children. Once a maintenance enquiry is instituted and the father submits that he is willing to pay but is unemployed, there is nothing that can be done. However, the complainant is often encouraged to apply for the state's child support grant. At this stage, the burden gets shifted to the state. All considered, it seems glaringly irresponsible for fathers to shift their maintenance responsibility to the state.

In the case of S v Visser66 the Supreme Court of Appeal supported the principle of periodic imprisonment for a maintenance defaulter to ensure that the rights of the child were upheld. The court stressed that the best interests of the child remain of paramount importance in maintenance matters. 67

It is therefore submitted that the Maintenance Act alone as a state machinery in the enforcement of the parents duty of support is inadequate. Furthermore, although the government has the responsibility to provide social security, such security can only be provided within the state's available resources and with a population of nearly 50 million people and almost half unemployed it would seem difficult for the state to realise this constitutional mandate.68

It is clear from the interpretation of these articles that it is the primary responsibility of parents to care for their children. That is why it is important for government to consider other options to alleviate the burden on itself. The discussion below will determine whether the state through the (CSG) programme has positively assisted where parents are unable to contribute adequately. The (CSG) is the state's largest social assistance programme in terms of the number of beneficiaries reached. Its purpose is to ensure that caregivers of young children (which in most cases are women) living in abject poverty are able to access financial assistance in the form of cash transfer to supplement, rather than replace household income.69

\section{The (CSG) Programme}

A child support grant is money paid to the primary care giver to provide for the child's basic needs. ${ }^{70} \mathrm{~A}$ primary care giver

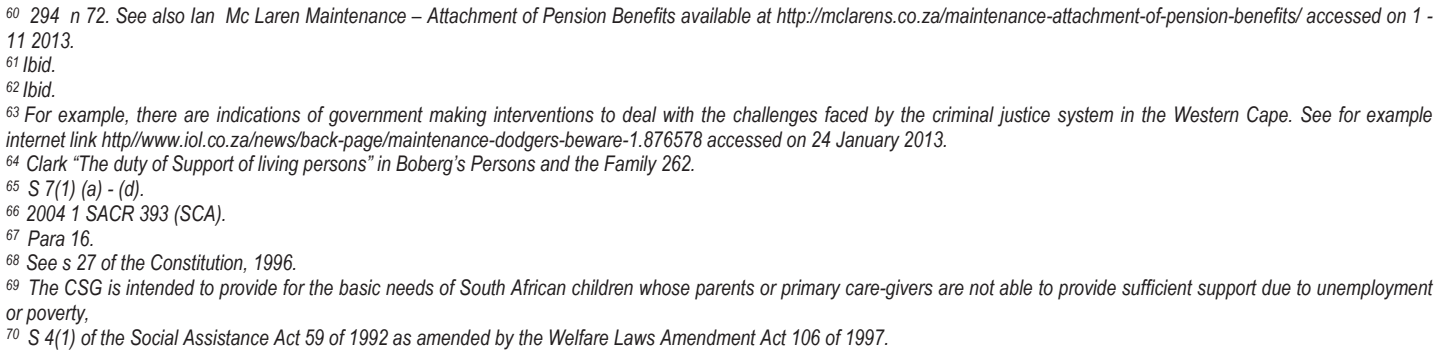


is defined as a person who takes primary responsibility for meeting the daily needs of the child. The concept of the primary care giver was introduced because of an unacceptable number of South African children who do not live in a nuclear household setting, some live with their extended families or with someone else. Even in these settings children are entitled to basic needs. It is therefore, clear that the primary care giver might not necessarily be the child's parent but also a person who might have care of the child in terms of a court order ${ }^{71}$ or a parental responsibility and rights agreement. $^{72}$

\subsection{Background}

The CSG programme was conceptualised to ensure that more South African children in need would gain access to social assistance, than was the case with the racially-based State Maintenance Grant. ${ }^{73}$ The State Maintenance Grant was a means-tested grant administered to a mother who was not receiving financial support from her partner or the father of her children or a mother who was widowed or 'deserted'. ${ }^{74}$ Recommendations were made including that the SMG be phased out.

In 1997 the new CSG was introduced and was limited to children under seven years old. It targeted the poorest $30 \%$ of South Africa's children. ${ }^{75}$ Over time not only did the value of the grant change, but also the age of illegibility. The initial value of R100 remained unchanged until 2001, when the grant was increased to R110. Subsequently, it was increased to R130 in April 2002, to R140 in October 2002 and to R160 in 2003. ${ }^{76}$ The current value of the grant is R310 from April 2014.The amount was increased as an effort to assist the poor in coping with the current economic challenges such as high inflation, high petrol price and rising food prices. As far as the age of illegibility is concerned, government announced in February 2003 that children under 9 years would be targeted to receive the grant from 2003/2004, children under 11 years were targeted from 2004/05 and children under 14 years were targeted from 2005/06. The amount of the grant from $1^{\text {st }}$ of April 2012 is R280 for every child who qualifies.

\subsubsection{Who can apply?}

A primary care-giver of the child or the children in his or her care. A primary care-giver can be a parent, grandparent, or anyone who is mainly responsible for looking after and providing for the basic needs of the child. The grant is paid to the primary care-giver and in all cases the grant follows the child. This means that if someone else becomes the primary care-giver, then the grant goes to that person. The person who applies must be over the age of 16 years, be living with the child in South Africa at the time of the application for the grant. Furthermore, the applicant must also be a South African citizen or a permanent resident and pass the means test. ${ }^{77}$

However, an applicant cannot receive the grant on behalf of the child or children if they are being paid to look after a child; someone else is already getting a grant for the child; they represent an institution which takes care of the child and they do not qualify in terms of the means test. ${ }^{78}$

\subsubsection{What is a mean's test?}

A means test is the test used to measure the financial status of the applicant. In order to receive a grant, an applicant's financial income should be below a certain level. In determining eligibility to receive a grant a distinction is made between families living in rural areas and families in urban areas and the household's income differs in determining the means threshold. The means test developed in 1998 has changed over time and in 2008 the eligibility threshold was equal to 10

\footnotetext{
71 Section 23 of the Children's Act.

72 Section 1(1) of the Children's Act.

${ }^{73}$ Social security legislation in South Africa which was primarily aimed at assisting both children and pensioners has always been racially defined. The Children Protection Act of 1913 was one of the first significant laws passed after the creation of the South African State in 1910 and can be seen as the first step in the creation of a South African social security system. The Act was racially discriminatory in that it provided for maintenance grants for white children, and excluded children of other population groups. See in this regard K Makino Social Security Policy Reform in Post -Apartheid South Africa: A Focus on the Basic Income Grant available at http://202.244.105.132/Japanese/Research/Project/2006/pdf/407.05.pdf accessed on 10/12/2013.

74 E Coetzee \& J Streak Monitoring Child Socio-Economic Rights in South Africa: Achievements and Challenges Idasa (2004)186.

75186.

76188.

77 Paralegal Manual; Social Grants available at http://www.paralegaladvice.org.za/docs/07_full.html accessed on 1 November 2013.

78 Ibid.
} 
times the value of the grant. Since then, the amount, the means test and threshold has gradually increased. ${ }^{79}$ Anyone applying for a social grant must qualify through the means test. This is a way of measuring a person's income and assets. If the person applies for a grant, SASSA will evaluate their income and assets. If the income and/or assets are higher than the threshold set by government, then they will not qualify for a social grant. The means test depends on their own income and assets if they are not married, and on the income and assets of the applicant and their spouse if married irrespective of whether they are married in community of property or out of community of property. ${ }^{80}$ However, the amount changes every year. The asset threshold set is the same for all other grants but the income threshold differs. At present the income threshold is set at R33 600 for a single caregiver and R67 000 per year for married couples. ${ }^{81}$

\subsubsection{Have the children benefited from the CSG programme?}

First, the CSG programme at its inception failed to provide for all children because of its eligibility requirement that only catered for needy children under the age of 14 , whereas the Constitution defines a child as any person below the age of 18. ${ }^{82}$ This policy therefore means that children between the ages of 14 and 18 years never benefitted and consequently they were denied the right to have access to social security through the CSG programme. ${ }^{83}$ Our statutory law also defines a child as any person below the age of $18 .{ }^{84}$ It could be argued that the CSG programme discriminated against children between the ages of 14 and 18 and therefore deprived them of the right to be treated equally with other South African children. The state has a responsibility to fulfill the rights of children to social security where the parents are unable to do so. ${ }^{85}$ Furthermore, it is also against the best interests of the child standard that is regarded as the paramount consideration in all matters concerning the child. ${ }^{86}$ However, this situation has now been remedied as the grant has been extended to all children up to the age of 18 years.

Secondly, the application process requires that the applicant, that is, the parent or care-giver, verify their own identities and they are also required to produce a birth certificate of the intended beneficiary. This requirement creates problems in that poor families usually do not keep records of birth because of illiteracy and other logistical challenges and it is for these families that the CSG is needed most. Therefore, children sometimes are deprived of the possibility of accessing the grant because of the absence of birth certificates.

Thirdly, there is little change with regard to the means test as conceived in 1998 and this poses a challenge to the poor in that failing to adjust the means test for inflation means that the government has not taken into account the fact that the decided poverty level or line identified at the time of the programme inception has increased due to inflation. ${ }^{87}$ That is to say, although the means test and threshold had increased gradually over time, ${ }^{88}$ the current high food prices, electricity hikes, services and fuel prices make it very difficult for the poor to survive. It is submitted that the R300 per month grant is not enough in the current South African economy when the money received will not only be used for food and basic necessaries but also for education and health care. The small benefit level of the grant is not linked to a transparent, accepted assessment of the needs of poor children, and the costs of their support. It is therefore, submitted that the current means test is not a proper yardstick to assess the needs of the beneficiaries. It is highly unlikely that there exists a comprehensive study on the needs of individual poor children, what it really takes to adequately care and provide for a child.

Fourthly, the CSG programme does not reach children living on the streets and child-headed households because an adult care-giver is still required as the applicant. Many of the needy South African children are therefore still excluded and the government through the national Department of Social Development had failed in its duty to make sure that, children as the most vulnerable members of the society, are duly protected. It is submitted that an absent father is also to blame because it is the primary responsibility of parents to provide for their children. The state assists when it is clear that the parents are unable to do so. There are also families and carer's who have to cater for more than six children in need of maintenance and the CSG is limited to only six children. The implication is that additional children cannot benefit and this is certainly not in the best interests of the child.

\footnotetext{
79 The South African Child Support Grant Impact Assessment: Evidence from a survey of children, adolescents and their households May 2012 at http://www.unicef.org/southafrica/SAF_resources_csg2012s.pdf accessed on 10 December 2013.

80 Paralegal Manual ibid $n 70$.

81 The South African Child Support Grant Impact Assessment $n 72$

$82 S 28$ (3).

83 S 27 of the Constitution.

$84 \mathrm{~S} 1$ of the Children's Act.

85 S 27 of the Constitution.

${ }^{86} \mathrm{~S} 28$ (2) of the Constitution.

${ }^{87}$ Coetzee Monitoring Child Socio-Economic Rights in South Africa: Achievements and Challenges 190

${ }_{88}$ See in this regard $n 73$ above.
} 
Liebenberg and Tilley further argued that the means test and some of the other conditions applicable to the grant have negative gender implications, for example, the primary care-giver who in the most instances will be a woman could not be able to provide the requisite proof of household income because most of them are not in the formal employment sector, some are domestic workers who are often not registered by their employers, others are grandparents whose sole income is their state pension grants. ${ }^{89}$ Furthermore it is argued that the two-tier means test with a high income threshold for persons living in informal dwellings and rural areas may give rise to perceptions of unfairness and is susceptible to claims of unfair discrimination. ${ }^{90}$

\section{Recommendations to Improve the Situation}

As evident from the foregoing discussion maintenance presents a serious challenge to South Africa for a variety of reasons. These challenges, however, do not seem to lie in the law but in its application. The country has a sound system that provides a framework that gives meaning to the tenets of the Constitution that makes it a right for children to be supported. It goes further and provides mechanisms to enforce compliance by both parents. The justice system, however, does not seem to be well-equipped to deal with the problem of defaulting parents, dominantly fathers, who shy away from their responsibility. The law seems teeth-less if experience of children needing maintenance without success is considered. Men are generally expected to provide for their families and there is a pressing need to reinforce this responsibility. Women should also be encouraged to seek employment and contribute adequately to the maintenance of their children. Women must be empowered and encouraged to take responsibility for their sexuality, determine when they are ready to have children and the number of children they desire. This will eventually lessen their dependency on government grants.

Furthermore, government should consider introducing limitation on the number of children individuals should have following the examples of developed countries like China and Japan. The number of children receiving the CSG in South Africa rose from 5913719 in 2005 to 11044494 in $2014 .{ }^{91}$ This is unacceptably high considering the high levels of poverty and unemployment.

The ministry of Basic Education should also consider the possibility of introducing a subject on sexuality to cover issues of family planning and birth control in the primary school curriculum. This will empower young girls and boys because in African culture these issues are never discussed openly. Once the children have been empowered from an early age, hopefully this will impact positively on their fertility rates and reduce the burden on the government. Young adults could maybe take parental responsibilities towards their children seriously and not rely on state's support. Most importantly the government will then divert money on support grants budgets to improve service delivery, establish in service training centres in trying to alleviate poverty and the likelihood is that more children will hopefully receive the support they are entitled to from their parents and carers

Government should consider job creation initiatives and seriously reconsider the issue of grants and most importantly the Maintenance Act as a state's machinery in the enforcement of the parent's duty of support. It is when one juxtaposes the parental duty to support with state initiatives such as the CSG that the disjunture between policy, law and practice are exposed. For example, it is little comfort that the Constitution protects a particular child's right to maintenance if the justice system is paralysed when it comes to enforcing that right.

It is in that light that while the CSG system is laudable and initiative, it has the potential to usurp the societal responsibility and legal duty placed on the shoulders of all parents. There has to be a way that minimizes the gap between the two in such a way that the state is only left with the responsibility to maintain those that are economically unable to receive assistance (i.e. maintenance) from those legally bound to do so. Needless to say, a system such as the CSG system in a developing country such as South Africa is not sustainable, to say the least. It is submitted that, the R280 grant seems not to make any substantial difference in the children's lives except that they would have a meal for a day or few days. It is submitted further that although not all problems encountered in the maintenance of children in South African law are caused by the absent fathers, they do exacerbate the problem and deplete state resources.

Furthermore, although only South Africans are eligible for the grant, with the porous or inadequate border controls and corrupt home affairs officials, the CSG is abused and it is not far-fetched a possibility that even foreign nationals can access the grant albeit in illegal ways.

It is with these broad sentiments that the recommendations below are made. There is a need for government to

${ }^{89}$ MP Olivier, MC Okpaluba, N Smith \& M Thompson Social Security Law-general principles (1999) 266. Furthermore, most of these women have very limited formal education, they are unemployed, some run small businesses' with limited incomes for example, selling of soft goods.

$90 \mathrm{lbid}$.

${ }^{91}$ A Statistical Summary of Social grants in South Africa available at http:// www.sassa.gov.za/index.php.../statistical reports 2014 accessed on 21-04- 2014 
reconsider the CSG system in view of the current population growth and economic challenges. It is proposed that the money earmarked by government for grants could be channeled into development programmes and grant beneficiaries would then benefit directly from those programmes. Young mothers could be encouraged to return to school and their children be placed in nursery schools that are fully subsidised by government. Fathers of children receiving support grants, some of whom are probably illiterate or semi-literate, could be fully trained by government in various sectors of the economy for example, in the construction industry and receive salaries to contribute fully in the support of their children. Furthermore, it is submitted that, it is ineffective to limit the number of children of an individual who are eligible for a support grant to six rather government should empower rural communities and the public in general on issues of birth control, quality life, benefits of having a small family, pride and the satisfaction of providing for one's family. It is submitted that it is doubtful whether the CSG can be sustainable in the future in its present form.

It is further submitted that, in order to prevent non South Africans from benefitting from the CSG, the government must make provision of mobile home affairs offices at provincial public hospitals. Where there are no public hospitals as it is the case in some rural communities then each clinic could have a part time home affairs official to record the birth of children then forward the information to the home affairs department for capturing and issue of the birth certificate.

\section{References}

Boberg, P.Q.R. (1997) The Law of Persons and the Family Juta Cape Town .Cronje,

Coetzee, E. \& Streak, J. (2004) Monitoring Child Socio-Economic Rights in South Africa: Achievements and Challenges. Idasa

D.S.P. \& Heaton, J. (2010). South African Family Law (3rd ed.). Lexis Nexis. Butterworths Durban.

Domingo, W. et al (2012). Law of Persons and the Family Pearson Education in South Africa (Pty) Ltd .

Robinson, J.A. et al (2008). Introduction to South African Family Law (3rd ed.).

Robinson, J.A. et al (1997). The Law of Children and Young Persons Butterworths Durban.

Skelton, A. et al (2010). Family Law in South Africa (1st ed.).

Spiro, E. (1985). The Law of Parent and Child (4th ed.). Juta Cape Town.

Olivier, M.P. et al (1999). Social Security Law- general principles Butterworths Durban.

\section{Journal articles}

Clark, B, Duties of Support of living persons in Boberg's Law of Persons and the Family (1999) 2nd ed 233, 259-260.

Clark, B, (1999) Enforcement of the duty of support in Boberg's Law of Persons and the Family 292.

\section{Case law}

Bannatyne v Bannatyne and Another 2003 (2) SA 363 CC.

Burger v Burger 2006 (4) SA 414 D.

Chamani v Chamani 1979 (4) SA 804 W.

Government of the Republic of South Africa v Grootboom and Others 2001 (1) SA 46 CC, 2000 (11) BCLR 1169 CC.

Magewu v Zozo 2004 (4) SA 578 C; 2004 (3) ALL SA 235 C.

McCall v McCall 1994 (3) SA 201 C.

Mentz v Simpson 1990 (4) SA 455 A.

Mngadi v Beacon Sweets \& Chocolates Provident Fund 20045 SA 388 D

Smith v Smith 1980 (3) SA 1010 O.

Soller v Maintenance Magistrate, Wynberg 2006 (2) SA 66 C.

S v Visser 2004 (1) SACR 393 SCA.

\section{Legislation}

Children's Act 38 of 2005

Children Protection Act 25 of 1913

Constitution of the Republic of South Africa Act of 108 of 1996

Maintenance Act 88 of 1999

Social Assistance Act 59 of 1992

Welfare Amendment Act 106 of 1997

\section{Internet Sources}

Children's Institute, UCT Available: http://www.childrencount.ci.org.za/social (January 1, 2013) 
Dunlop S "Can South Africa afford a Welfare state?" Available: http://www.parent.com/preschool accessed 23/01/2013

Hosken G, SA's Children's Misery Available: http://www.timeslive.co.za August 24, 2013)

Makino K, Social Security Policy Reform in Post-Apartheid South Africa: A focus on the Basic Income Grant Available: http:// 202.244.105.132/Japanese/Research/Project/2006/pdf/407.05.pdf. (December 10, 2013)

McLaren I, Attachment of Pension Benefits Available: http://mclarens.co.za/maintenance-attachments-of-pension-benefits/ (November 1, 2013)

Paralegal Manual: Social Grants Available: http://www.paralegaladvice.org.za/docs/o7fullhtml. (November 1, 2013)

Unicef: South African Child Support Grant Impact Assessment: Evidence from survey of children, adolescents and their households May 2012 Available: http://www.unicef.org.Southafrica/SAF resources csg2012s pdf. (December 10,2013) 